\title{
Polymerase chain reaction (PCR) for the rapid detection of Salmonella in desiccated coconut (DC)
}

\author{
Jayaratne, D.L. ${ }^{*}$, Kanakaratne, U.N.D.S. ${ }^{2}$ and Shanthichandra, W.K N. ${ }^{3}$
}

\begin{abstract}
This study was carried out to develop a polymerase chain reaction (PCR) protocol for the detection of Salmonella in desiccated coconut (DC). For the PCR detection of Salmonella, genomic DNA was extracted using the 'boiling lyses' method and the reaction was carried out with Salmonella genus specific primers enabled to amplify $457 \mathrm{bp}$ sequence covering invA and invE genes. Samples of DC produced in mills already tested for Salmonella using conventional cultural methods gave identical results with the present PCR method indicating its suitability for adoption in routine testing.

The sensitivity checked using DNA extracted from artificially inoculated DC with serially diluted inoculum of Salmonella M1 type showed that the developed PCR method can be used to detect very low levels of contamination of Salmonella as low as 4 CFU/g in DC.

The method described here reduces the testing and detection time from 6 days to 24 hours ensuring exporters to obtain Salmonella test reports just prior to shipment.
\end{abstract}

Key words: Polymerase Chain Reaction (PCR), Salmonella, Desiccated coconut (DC)

\footnotetext{
${ }^{1}$ Department of Microbiology, Faculty of Science, University of Kelaniya, Sri Lanka.

${ }^{2}$ No. 54, Kithul Watte Road, Colombo 8, Sri Lanka

${ }^{3}$ Asian and Pacific Coconut Community, P.O. Box 1343, Jakarta, Indonesia.

(* Corresponding Author Email: jayarat@kln.ac.lk)
} 


\section{Introduction}

Sri Lanka is one of the pioneers in manufacturing the desiccated coconut and as per the reports it has commenced more than 107 years before using the technologies developed in Sri Lanka (S B Ratnayake, 2005). DC is the dried coconut kernel hygienically prepared in the form of flakes, threads and granules used as a food and manufactured mainly for export purposes. Sri Lanka plays a major role in the export of DC with the existing installed capacity of 100,000 MT per year (CDA statistics 2003). Desiccated coconut industry itself is a major contributor to the national economy of the Sri Lankan Government and in 2005 it's contribution is 19 million US\$.

Bacteria Salmonella is a major cause of food-borne infections in worldwide. Almost all vertebrates appear susceptible to the infection caused by the different species of Salmonella (Joseph et al., 1999). Among 2000 known species, S. typhi and S. paratyphi are primarily human pathogens. Human infection is initiated by ingestion of a sufficient number of pathogen to overcome the defense mechanism in the human body system. Wilson et al. in 1955 reported that to cause a natural infection approximately $10^{2}$ to $10^{3}$ bacterium cells are sufficient. The extent of human infection is determined by the prevalence of bacterium in food and the availability of favorable conditions for the pathogen to further multiply in the contaminated food.

The Salmonella contamination of desiccated coconut causing an outbreak of typhoid fever was recorded for the first time in 1953 in Australia (Wilson et al., 1955). Later, a survey carried out in the United Kingdom revealed that the 76 samples out of 851 samples of DC imported from Sri Lanka have been found contaminated with Salmonella, predominantly $S$. paratyphi (Galbrraith 1960). The compulsory introduction of high stringent sanitary procedures into the Sri Lankan DC industry was a direct result of these findings and since then the incidence of contamination has diminished.

As a result, mandatory sanitary measures have been imposed to the DC industry in Sri
Lanka and each consignment of DC export accompanied a microbial quality certificate issued by a recognized authority indicating the absence of Salmonella by testing DC samples. The conventional culturing techniques and biochemical tests take an average 6 to 7 days to analyze a DC sample for Salmonella contamination. This delay in test procedure causes serious problems for the DC industry and some times urgent shipments made prior to obtaining the test results have been rejected by the importing countries. Thus there is a need to identify a rapid method to analyze DC for Salmonella contamination in order to minimize delays and avoid rejection of shipments.

Since the conventional bacteria cultural methodologies and biochemical tests for identification of bacterial species are time consuming and caused delays in export consignments, the necessity arises to look for a quick, accurate and fast detection technique. The polymerase chain reaction (PCR) is a biochemistry and molecular biology technique for isolating and exponentially amplifying a fragment of DNA, via enzymatic replication (Smithsonian Institution, 2006). PCR technique, a novel molecular biological method has been widely practiced to detect the microbial infections. This method has been successfully applied for the detection of various pathogens such as Listeria monocytogenes, Camphylobacter spp., Vibrio spp., Escherichia coli, Shigella spp. and Salmonella spp. in meat, fish, milk and processed food industries. PCR test results using Salmonella specific oligonucleotide DNA primers showed advance features, such as spped, specificity, sensitivity and accuracy in the detection of Salmonella spp. contaminated in food. The PCR is also easy to perform and can be used to analyze large numbers of samples compared to the biochemical methods (Stone et al., 1994).

The purpose of this study is to establish a PCR-based detection technique as a quick, accurate and fast technique to detect Salmonella in DC samples to avoid delays in issuing microbial quality certificates. 


\section{Materials and method}

The Desiccated Coconut samples were collected from the DC mills operated in the North Western Province in Sri Lanka as per the sampling methodology adopted by the Coconut Development Authority (CDA), Sri Lanka. The samples were drawn from the randomly selected $50 \mathrm{~kg}$ DC bags on the basis of $10 \%$ from each batch of DC production packed in 50kg bags.

From each $50 \mathrm{~kg}$ bag approximately $25 \mathrm{~g}$ two separate samples were collected into sterilized polythene bags under the aseptic condition and then sealed by using the polythene sealer to avoid contaminations during the transportation to the laboratory.

Biochemical and serological methods of Salmonella detection and identification:

DC samples of more than 4000 were tested according to the conventional cultural methods consisting of pre-enrichment in Buffered Peptone Water (BPW), selective enrichment in Rapparport Vassiliadis Soya peptone (RVS) broth, plating on selective media; Xylose Lysine Decarboxylase (XLD) and Brilliant Green Bile Agar (BGA) for the detection of Salmonella bacteria. The suspected bacterial colonies grown on these selective medias were then tested by the api 20 E strips (Bio Meieux) and slide agglutination test with polyvalent ' $\mathrm{O}$ ' and ' $\mathrm{H}$ ' Salmonella antigen for conformity.

\section{DNA extraction from five known bacterial cultures for PCR:}

Methodology described by Guo et al., (1998) was adopted in extraction of DNA from bacteria. Six known bacteria namely, Salmonella M1 type, S. typhi, S. paratyphi, S. typhimurium, Bacillus subtilis and Escherichia coli were cultured separately in nutrient agar plates and then the inoculated plates were incubated at $37^{\circ} \mathrm{C}$ for 24 hours. Single colonies grown in each plate were separately dissolved in $50 \mu 1$ of sterilized distilled water (SDW) contained in micro- centrifuge tubes and then those bacterial cell suspensions were placed in a boiling water bath for 10 minutes.

The cell lysates in each micro-centrifuge tube were centrifuged at $13000 \mathrm{rpm}$ for 30 seconds and the supernatants from each tube were taken separately. Supernatants were stored at $-20^{\circ} \mathrm{C}$ to be used as the template DNA for PCR.

\section{Preparation of DC samples as the positive controls:}

The DC samples of $25 \mathrm{~g}$ which was free from salmonella were separately inoculated with $100 \mu 1$ of Salmonella M1 type inoculums prepared in SDW by dissolving single colonies separately. The inoculated samples were subjected to pre-enrichment for 18 hours at $37^{\circ} \mathrm{C}$ in $125 \mathrm{ml}$ of buffered peptone water (BPW) and the DNA were extracted according to thermal treatment method.

\section{Sensitivity tests for the detection technique:}

Salmonella bacteria free DC samples of $25 \mathrm{~g}$ were separately inoculated with $100 \mu \mathrm{l}$ of Salmonella M1 type and then prepared dilutions series of $10^{-1}$ to $10^{-7}$ in SDW. The bacterial cell counts of these dilutions were also made as per the 'pour plate method' by inoculating nutrient agar plates with $100 \mu \mathrm{l}$ of each dilution separately. These cell counts were used to determine the sensitivity of PCR for the detection of Salmonella

\section{Pre-enrichment of Salmonella in DC samples for DNA extraction:}

The biochemical tests and serological methods were used to identified the Salmonella positive DC samples The samples of $25 \mathrm{~g}$ were subjected to the pre-enrichment for 18 hours at $37^{\circ} \mathrm{C}$ in $125 \mathrm{ml}$ of BPW. The DNA was extracted according to the thermal treatment method. (Winters et al., 1998). 
Thermal treatment method for the extraction of DNA from Salmonella in pre-enriched DC samples:

The method was adopted from Winters et al., 1998. Thirty milliliters of each pre-enriched samples were centrifuged at $1000 \mathrm{rpm}$ for 10 minutes. The supernatants $25 \mathrm{ml}$ of each sample were separately taken and centrifuged again at $6000 \mathrm{rpm}$ for 15 minutes. The supernatants in each sample were removed and the pellets were separately dissolved in $1 \mathrm{ml}$ of SDW in microcentrifuge tubes and centrifuged at $13000 \mathrm{rpm}$ for 10 minutes. The supernatant in each tube were discarded and the pellets were dissolved in $100 \mu \mathrm{l}$ $1 \%$ Triton X-100 in SDW and boiled in a boiling water bath for 10 minutes.

The cell lysates were centrifuged at 13000 rpm for 30 seconds and the supernatants from each tube were taken separately and stored at $20^{\circ} \mathrm{C}$ to be used as the template DNA for PCR.

\section{PCR for the detection of Salmonella:}

The method adopted from Guo et al., 1999. Salmonella specific primers for the conserved sequences of genes $\operatorname{Inv} \mathrm{A}$ and $\operatorname{Inv} \mathrm{E}$ have been used for PCR. These primer sequences are 5'TGCCTACAAGCATGAAATGG3' and 5'AAACTGGACCACGGTGACAA3'. The reactions were carried out in $25 \mu 1$ reaction mixtures each contained $2.5 \mu \mathrm{l}$ 10XPCR buffer $(50 \mathrm{mM} \mathrm{KCl}, 10 \mathrm{mM}$ Tris- $\mathrm{HCl}$ and $0.1 \%$ Triton $\mathrm{X}-100), 1 \mu \mathrm{M}$ of each primer, $100 \mu \mathrm{M}$ each of four deoxyribonucleotides, $1.5 \mathrm{mM} \mathrm{MgCl}_{2}, 1.25$ units of Taq DNA polymerase (Promega) $2 \mu \mathrm{l}$ of extracted DNA as the template. The thermal cycling programme was set in a TECHNE FlexiGene thermal cycler. The samples were initially denatured at $94^{\circ} \mathrm{C}$ for 2 minutes. Thirty five cycles of amplification were run for 45 seconds at $94^{\circ} \mathrm{C}, 45$ seconds at $50^{\circ} \mathrm{C}, 45$ seconds at $72^{\circ} \mathrm{C}$ with the final extension continuing for 7 minutes. Each amplified products of $20 \mu 1$ aliquots separately mixed with $5 \mu$ l loading dye were subjected to electrophoresis through $2.0 \%$ agarose gel containing ethidium bromide $0.5 \mu \mathrm{g} / \mathrm{ml}$. The amplified DNA products were visualized by exposing the gel to $312 \mathrm{~nm}$ UV rays on the UV Transilluminator (Uvitec $312 \mathrm{~nm}$ / STX-35MS) and photographed on a Polaroid film with a Polaroid camera (Polaroid Gelcam).

\section{Results and discussion}

The reliability and specificity of the PCR method for detection of Salmonella was tested using extracted DNA from five known Salmonella species as the templates at the first step of developing this method. All Salmonella DNA were amplified generating a characteristic 457 bp product but not DNA of $E$. coli and $B$. subtilis used as controls (Figure 1) indicating the reliability of the test procedure and the specificity of the primers for InvA and $I n v \mathrm{E}$ genes for the PCR detection of Salmonella species. The results are similar to those of Guo et al. (1998) who studied 71 Salmonella isolates belonging to five different serotypes.

Also, the PCR reactions with boiling-lyses extracted DNA from inoculated DC samples with known Salmonella spp. had generated 457 bp products without any non-specific amplification from E. coli and B. subtilis inoculated samples.

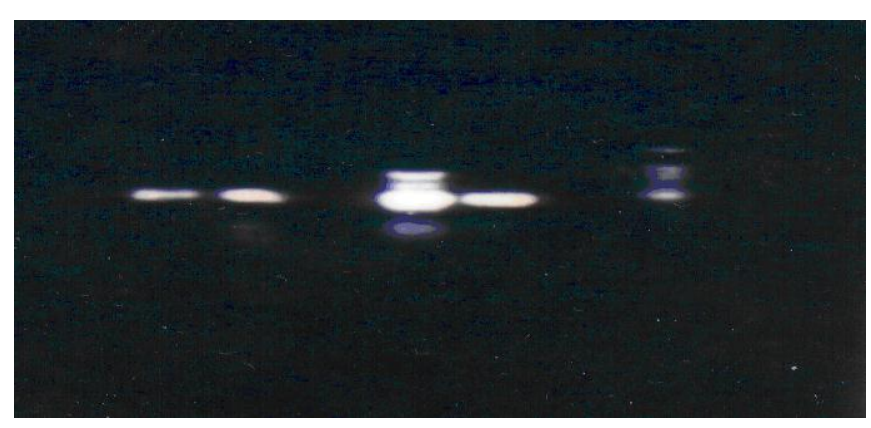


Figure 1: Agarose gel electrophoresis of the PCR amplified DNA for bacterial genomic DNA extracted from six known bacterial cultures. Lane 1: Salmonella typhi; Lane 2: S. paratyphi; Lane 3: Bacillus subtilis; Lane 4: Salmonella M1 type; Lane 5: S. typhimurium; Lane 6: Escheriatia.

\section{$\begin{array}{llllllllll}1 & 2 & 3 & 4 & 5 & 6 & 7 & 8 & 9 & M\end{array}$}

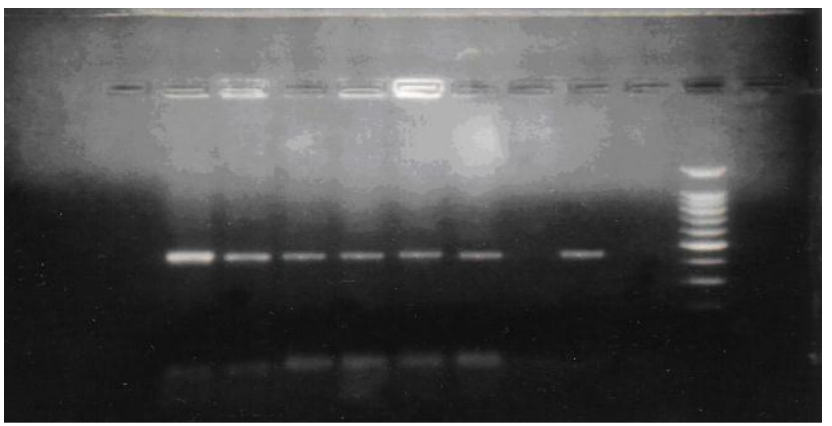

Figure 2: Agarose gel electrophoresis of the PCR amplified DNA for bacterial genomic DNA extracted from inoculated DC samples with serially diluted Salmonella M1 type. Lanes 1 to 7: The dilutions 10-1 to 10-7; Lane 8: Positive control.

\section{$\begin{array}{llllll}M & 1 & 2 & 3 & 4 & 5\end{array}$}

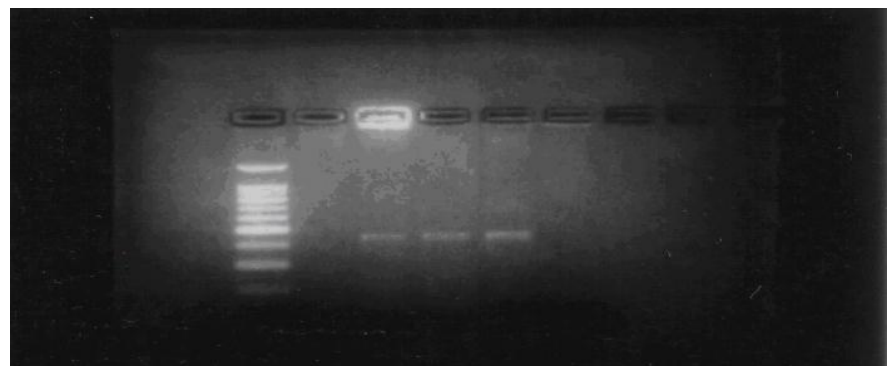

Figure 3: Agarose gel electrophoresis of the PCR amplified DNA for bacterial genomic DNA extracted from naturally

The DC samp Lanes 1 \& 5: Salmonella negative. contaminated DC samples. Lanes 2, 3 \& 4: Salmonella positive;

dilutions containing 1

M1 type were used to determine the sensitivity of PCR for the detection of Salmonella. The bacterial counts of these samples were determined by 'pour-plate method' inoculating $100 \mu \mathrm{l}$ of each dilution in to nutrient agar plates. Therefore, the PCR was carried out using the boiled lysates obtained from pre-enriched DC samples which were inoculated with known counts of Salmonella M1 type. The results revealed that the $10^{-1}$ to $10^{-6}$ dilutions of the initial suspension of Salmonella cells inoculated
Irs of pre-enrichment traction method were positive for PCR detection of Salmonella M1 type (Figure 2) and produced the results within 24 hours. The conventional methods used at presently showed similar detection limit of until $10^{-6}$ but produced the results only after 6-7 days. Estimation of viable bacterial count carried out using the pour-plate method revealed that $10^{-6}$ dilution of the inoculum consisted of 1000 $\mathrm{CFU} / \mathrm{ml}$. The $25 \mathrm{~g}$ DC samples inoculated with $100 \mu \mathrm{l}$ volume of $10^{-6}$ dilution containing 100 cells. Therefore the analysis of DC 
contaminated with Salmonella using the conventional and PCR methods are sensitive to detect as few as $4 \mathrm{CFU} / \mathrm{g}$ of DC contaminated with Salmonella M1 type.

The experiment carried out using naturally contaminated DC with Salmonella explain that the boiling-lyses extraction of DNA from the contaminated DC samples can be effectively done after employing the pre-enrichment and using $0.1 \%$ Triton X-100 to make the cell lysate. Resultant DNA bands from the PCR reactions with DNA extracted from three DC samples which have been confirmed positive with cultural and biochemical methods indicates that the developed PCR method is suitable for the routing detection of Salmonella in DC.

\section{Acknowledgement}

Authors are grateful to staff of the Department of Microbiology, Faculty of Science, University of Kelaniya who helped with this study and staff of the Quality control and Quality assurance Division and the Processing Development Division of the Coconut Development Authority, Sri Lanka for the valuable support, guidance and allowed to use their Laboratory.

\section{References}

API 20 E Instruction Manual (2000) BioMerieux, Inc. An Identification system for Enterobacteriaceae 20 100/20160.

CDA, 1972. Microbial method Manual, Coconut Development Authority, Colombo 05, Sri Lanka.

CDA, 2003, Annual report, Coconut Development Authority, Colombo 05, Sri Lanka.
CDA, 2004. Sri Lanka Coconut Statistics, Coconut Development Authority, Colombo 05, Sri Lanka.

Galbrraith, S. L., Galan, J. E., Ginocchio, C., Costeas, $\mathrm{P}$ and Hedrick, P.,1960. Environment and Public Health. 28.

Guo, L., Killefer, J., Kenney, P. B and AmickMorris, J. D, 1998. Use of arbitrarily primed polymerase chain reaction to study Salmonella ecology in a turkey production environment. In Environment and Health, Division of Animal and Veterinary Sciences, West Virginia University, Moragantown, west Virginia 26506-61608.

Joseph, M. D., Smedt, S and Amick-Morris, J. D, 1999. Environment and Health 24: 3638.

Stone, G.G., Oberst, R. D., Hays, M. P., McVey, S and Chengappa, M. M, 1994. Detection of Salmonella serovars from clinical samples by enrichment broth cultivation - PCR procedure. In. Journal of Clinical Microbiology, July 1994: 17421749.

Smithsonian Institution (2006). The history of PCR,. Smithsonian Institution Archives, Institutional History Division. Retrieved 24 June 2006.

Wilson, A. K., Black, R., Levine, M. M., Brakette, R. E and Bustler, J. P, 1955. Typhoid fever and infection, Genus Salmonella, In Enterobacteriaceae. 143: 154-186.

Winters, D. K., O'Leary, A. E and Slavik, M. F, 1998. Polymerase chain reaction for rapid detection of Camphylobacter jejuni in artificially contaminated foods. In. Applied Microbiology 27. 163-167. 
Cord 2007, 23 (2) 